Ключевые слова: государственная власть, ветви государственной власти, избирательная власть, институты избирательной власти, Центральная избирательная комиссия.

\title{
Summary
}

Vlada Taroyeva. Electoral branch of power in modern Ukraine.

The article introduces that the electoral branch is gradually being formed into an independent branch of state power in Ukraine, in which special state authorities operate. The electoral branch is already a component of the separation of powers in a modern state, and this is an important guarantee of the rule of law and of the condition for the democratic functioning of state power. The electoral branch is becoming an integral component of the separation of powers mechanism. The development of Ukrainian statehood actualizes the need for appropriate scientific support for the institutionalization of power and legal regulation of its realization. The electoral branch as a branch of state power represents the powers to conduct preparing and holding elections and referenda, as well as to ensure, exercise and protect the voting rights and the right of citizens of a certain state to participate in a referendum, as well as the system of electoral bodies of different levels exercising these powers.

In Ukraine, electoral commissions led by the Central Electoral Commission (CEC) are special electoral authorities. Here we are faced with the problem of determining the nature of electoral commissions, and therefore the institutionalization of the electoral branch in Ukraine. The CEC of Ukraine is a permanent state collegial body vested with the power to organize preparing and holding elections to the public authorities. The main task of the CEC of Ukraine is to ensure the realization and protection of constitutional sovereign rights of citizens to elect authorities, to participate in referenda, as well as to express their will. In order to fulfill its responsibilities, the $\mathrm{CEC}$ is endowed with rights and powers allowing the involvement of public authorities of all levels in the electoral campaign process. The CEC is an independent and autonomous body, financed exclusively by the budget.

In the modern world, electoral branch has been institutionalized through the electoral authorities in many states, and in some of them it has been constitutionalized, that is, it has been enshrined in the legislation and in the constitution.

Similar processes are taking place in modern Ukraine. The creation of the theoretical foundations of the electoral branch from the viewpoint of general theoretical legal science and constitutional legal science will enable to raise the question of enshrining the electoral branch as a branch of state power in the Constitution of Ukraine.

Key words: state power, branches of state power, electoral branch, institutions of electoral branch, Central Electoral Commission.

DOI: 10.36695/2219-5521.1.2020.24

УДК $342.4(477)+336.1$

\section{А.М. ХУДИк}

Андрій Мирославович Худик, помічник судді управління з організаційного забезпечення Апеляційної палати Вищого антикорупційного суду*

ORCID: 0000-0003-3174-8428

\section{КОНСТИТУЦІЙНИЙ ПРИНЦИП ВСТАНОВЛЕННЯ ПОДАТКІВ І ЗБОРІВ ВИКЛЮЧНО ЗАКОНАМИ УКРАЇНИ}

Постановка проблеми. Конституція України закріпила право приватної власності як один із найважливіших елементів конституційного ладу. Саме цей принцип забезпечує приватним власникам можливість вільно використовувати належне їм майно, гарантує стабільність відносин власності, не допускає довільного позбавлення майна та непропорційності обмеження права приватної власності1. Водночас право власності, зокрема й приватної, не є абсолютним. Його здійснення має певні конституційні межі, встановлені, серед іншого, положеннями ч. 3 ст. 13, ч. 7 ст. 41 Основного Закону України, у яких зазначається, що власність зобов'язує і не повинна використовуватися на шкоду людині й суспільству, правам, свободам та гідності громадян, інтересам суспільства, погіршувати екологічну ситуацію і природні якості землі. Крім того, Конституція України, закріплюючи гарантії права приватної власності, зобов'язує кожного «сплачувати податки і збори в порядку і розмірах, встановлених законом»².

Вважаємо, що важливим аспектом у дослідженні проблеми конституціоналізації публічних фінансів в Україні $є$ юридична конструкція та зміст закріпленого в Конституції України фундаментального принципу правового регулювання податкової системи України - принципу встановлення податків і зборів виключно законами України, що і $є$ предметом розгляду у цій статті.

Аналіз останніх досліджень і публікацій. Правову природу та зміст конституційного принципу встановлення податків і зборів тільки законами України (з позиції конституційного права) досліджували такі українські та зарубіжні вчені: Н.С. Бондар, А.В. Бризгалін, Д.В. Віницький, Р.О. Гаврилюк, Г.А. Гаджієв, А.Н. Козирін, М.П. Кучерявенко, С.Г. Пепеляєв, А.А. Пилипенко, В.А. Соловйов, Є.В. Тарібо та інші.

Формулювання мети статті. Мета статті полягає у з'ясуванні правової природи та конституційних вимог до принципу встановлення податків і зборів виключно законами України.

Виклад основного матеріалу. Важливим конституційним принципом податкового права $\epsilon$ принцип встановлення податків і зборів «виключно законами України». Так, згідно з Конституцією України, податок може бути встановлений, змінений або скасований тільки законом. Це положення закріплено у двох статтях

(C) А.М. Худик, 2020

* Andriy Khudyk, Assistant judge Court of Appeal of the Supreme Anti-Corruption Court 
Основного Закону. Стаття 67 передбачає, що «кожен зобов’язаний сплачувати податки і збори в порядку і розмірах, встановлених законом». А п. 1 ч. 2 ст. 92 Конституції України містить, зокрема, положення, що «виключно законами України встановлюються... система оподаткування, податки і збори» ${ }^{3}$. Як наслідок, податки, що сплачуються не на основі закону, не можуть вважатися «встановленими законом».

Принцип встановлення податків і зборів тільки законом полягає в імперативній конституційній вимозі, відповідно до якої податки і збори, будучи формою обмеження права власності, повинні встановлюватися виключно законами. Побутує думка, що оподаткування як обмеження конституційного права власності, законно рівно настільки, наскільки це встановлено законом. Будь-який виняток має бути оснований лише на правилі. Правило ж у цьому випадку - недоторканність власності ${ }^{4}$. Отже, тільки через прийняття відповідного закону можна зобов’язати платника податків перераховувати частина свого доходу (майна) у дохід держави, не порушуючи при цьому конституційних гарантій недоторканності права приватної власності5.

Питання законодавчого регулювання оподаткування, безсумнівно, має важливе конституційне значення: «податок - необхідна умова існування держави» ${ }^{6}$. Встановлення податків законом, тобто актом найвищої юридичної сили, має вагоме практичне значення, зумовлене тим, що предметом податкового права, попри те, що воно не регулює відносин власності, є перерозподільні суспільні відносини у сфері публічних фінансів. Щоправда, ці суспільні відносини безпосередньо пов'язані з відносинами власності, а тому є особливо чутливими, резонансними в суспільстві ${ }^{7}$.

Сама необхідність встановлення податків законами продиктована не стільки завданням забезпечити реальність їхнього внесення до бюджету (це можна виконати й по-іншому), скільки метою гарантувати захист власника від несанкціонованого втручання з боку держави. Сама історія податкового права нерозривно пов'язана $з$ процесами демократизації громадського життя, ідеєю правової держави. Основне завдання податкового права - захист права власності від безмежних домагань чиновницького апарату, підтримка балансу інтересів платника податків та держави ${ }^{8}$. Тому податкове право покликане обмежити фіскальний суверенітет держави і захищає платників податків від довільно, безпідставно встановлених податків.

Конституційна вимога про встановлення податків і зборів виключно законом являє собою один із принципів правової демократичної держави і має на меті гарантувати, зокрема, права та законні інтереси платників податків від сваволі й несанкціонованого втручання інститутів публічної влади (держави, інститутів муніципального права). Тільки закон, з огляду на його визначеність, стабільність, особливий порядок прийняття, може надати платникові податків достовірні дані для виконання податкового обов'язку. В іншому випадку принцип визначеності податкових зобов'язань може бути порушений, оскільки ці зобов'язання можуть бути змінені в гірший для платника податків бік у спрощеному порядку9.

Конституційний принцип встановлення податків виключно законом передбачає регулювання податкових відносин лише законом, що само собою унеможливлює прийняття конкретизуючих (розвиваючих) їхній зміст підзаконних нормативно-правових актів. Із цього приводу С.Г. Пепеляєв зазначає: «саме законодавча основа податків, що унеможливлює неоднозначне тлумачення тих або інших положень, створює необхідні умови для реального захисту прав платників податків. Тому поняття “податкове законодавство" має охоплювати закони, а також рішення місцевих органів влади, які видані на підставі Конституції» ${ }^{10}$. Саме така практика існує в багатьох зарубіжних країнах, де навіть не порушується питання про те, які нормативно-правові акти, що регулюють оподаткування, входять до поняття «податкове законодавство», а на конституційному рівні закріплено, що всі без винятку питання оподаткування вирішуються тільки на рівні законів. У зв'язку із зазначеним у літературі висловлюється думка, що питання оподаткування повинні регулюватися виключно особливими податковими законами, тобто законами, які спеціально призначені для регулювання податкових правовідносин.

На думку А.А. Пилипенка, закони, що регулюють принципово інші, неподаткові, відносини, не повинні містити норм, які стосуються податкового законодавства ${ }^{11}$. Важливо, щоб законодавство про податки і збори було більш жорстко відособлене від «неподаткового». Для цього, як зауважують Г.А. Гаджієв та С.Г. Пепеляєв, потрібно, щоб, по-перше, податкові відносини регулювалися тільки Податковим кодексом і прийнятими відповідно до нього законами; по-друге, визнати недопустимим регулювання податкових відносин і в законах, які мають іншу галузеву належність, і в законах, які стосуються інших інститутів права (зокрема інституту бюджетного права) ${ }^{12}$.

У Податковому кодексі України (далі - ПКУ) закріплено, що будь-які питання щодо оподаткування регулюються цим кодексом і не можуть встановлюватися або змінюватися іншими законами України, крім законів, що містять виключно положення щодо внесення змін до Податкового кодексу України та/або положення, які встановлюють відповідальність за порушення норм податкового законодавства (п. 7.3 ст. 7) ${ }^{13}$. Тобто податкові відносини мають бути регламентовані тільки ПКУ. Пріоритет податкових законів над неподатковими законами полягає в тому, що «якщо в неподаткових законах присутні норми, які так чи інакше дотичні до податкових відносин, то застосовувати їх можна тільки в тому випадку, якщо вони підтверджені і відповідними нормами, що містяться в податковому законодавстві»14. Розміщення податково-правових норм у неподаткових законах є порушенням конституційного принципу визначеності оподаткування.

Існує думка, що питання про внесення норм про оподаткування в «неподаткові» закони (як правило, це стосується пільг) важливе не тільки для доходів бюджету, а й рівності обов'язків громадян. Зокрема, з позиції ст. 67 Конституції України («кожен зобов’язаний») навряд чи можна знайти логічне пояснення тому, що окремі категорії громадян мають привілей не сплачувати деякі податки (чи сплачувати їх за зниженими ставками), як це інколи передбачено «неподатковими» законами. Практика показала, що належний контроль за наданням пільг можна забезпечити тільки в тому випадку, коли питання про пільги регулюватимуться лише законами, присвяченими оподаткуванню15. 
При цьому, як зауважує М.К. Теміржанов, настільки ж очевидно й те, що податкове законодавство не може регулювати питання, прямо не пов'язані з оподаткуванням. Положення податкового законодавства не повинні безпосередньо регулювати ті відносини, які стосуються предмета інших галузей та інститутів права ${ }^{16}$. Податкове законодавство не повинне втручатися, наприклад, у сферу цивільного чи господарського законодавства, визначати, як потрібно здійснювати господарську, економічну діяльність тими або іншими суб'єктами. Податкове законодавство має бути побудоване так, щоб воно якнайменше впливало на поведінку платників податків як учасників цивільного обороту і цивільно-правових відносин ${ }^{17}$.

Водночас потрібно зазначити, що зміст конституційного принципу встановлення податків і зборів суто законом не варто зводити лише до проблеми встановлення податків і зборів актами представницьких органів влади. Адже, як випливає зі ст. 3 та ст. 7 ПКУ, розглянутий принцип загалом означає обмеження нормотворчих повноважень виконавчих органів влади у сфері оподаткування. Виконавча влада не вправі змінювати або доповнювати законодавство про податки і збори.

3 позиції конституційних цінностей та відповідно до ст. ст. 6, 67, ч. 2 ст. 92 Конституції України надання законодавчому органу права встановлювати податки і збори означає також встановлення його обов'язку самостійно реалізувати це право. Конституція України не дає підстав для висновку про те, що податок може бути встановлений актом органу виконавчої влади (зокрема на основі делегованих повноважень) ${ }^{18}$. Вона обмежує пряме і непряме делегування повноважень щодо встановлення податків. Вважаємо, що делегування уряду повноважень із встановлення істотних елементів податкових зобов'язань не відповідає конституційно закріпленому розмежуванню повноважень між органами законодавчої і виконавчої влади (ст. 6 , ст. 85 , ч. 2 ст. 92 , ст. 116$)^{19}$.

Встановлення істотних елементів податку Кабінетом Міністрів України порушувало б конституційний принцип визначеності податкового зобов'язання (який випливає із конституційного принципу верховенства права $\left.{ }^{20}\right)$. Якщо ж істотні елементи податку i/aбо збору визначатимуться виконавчою владою, то завжди існує небезпека порушення принципу визначеності податкових зобов'язань, оскільки ці зобов'язання можуть бути змінені в гірший для платника податків бік у спрощеному порядку. Тому правотворчі повноваження виконавчих органів влади у сфері правового регулювання податкових відносин підлягають всеосяжному конституційному обмеженню. Це стосується також встановлення податкових пільг і переваг.

Зарубіжна конституційна практика знає приклади спеціального встановлення заборон на делегування повноважень із встановлення податків. Так, відповідно до Конституції Іспанії, «податки встановлюються законом. Регулювання введення, зміни або скасування податків не може бути делеговане органам виконавчої влади» (ст. 77) 21 . У Конституції Греції встановлено, що «визначення об' єкта оподаткування, податкового коефіцієнта, звільнень від податку або його зниження... не можуть бути об'єктом законодавчих повноважень, що передаються Парламентом іншим органам» (п. 4 ст. 78)22. Трапляються випадки повної заборони практики делегованого законодавства 3 питань оподаткування (наприклад, у Конституції Королівства Швеція (§ 7 гл. VIII)23).

У правовій державі сплата податків можлива тільки в законній формі з обов'язковим дотриманням передбачених законом процедур. Їхнє невиконання дозволяє розглядати стягнення податків як сваволю, неприпустиме обмеження права власності громадян і їхніх об'єднань. Вказівка в законі на правову форму податкових платежів робить їх легітимними, визначає їхнє місце серед інших обмежень конституційного права власності. Внаслідок чого випливає необхідність виділення принципу законності, що передбачає особливу правову процедуру встановлення податків і зборів 24 . Тож загальнодержавні податки та збори, відповідно до змісту ст. 67 Конституції України, можна вважати «встановленими законом», якщо вони встановлені належним суб' єктом - законодавчим органом, у належній формі - формі закону про внесення змін та доповнень до Податкового кодексу України та в передбаченому законом порядку і введені в дію відповідно до чинного законодавства.

Конституційний принцип встановлення податків і зборів виключно законом передбачає, що при введенні податків або встановленні обов'язкових платежів повинні дотримуватися конституційні вимоги до законодавчого регулювання будь-яких фінансових обтяжень і до обмежень прав та свобод громадян (ч. 1 ст. 64, ст. 67 Конституції України). Водночас цей конституційний принцип не обмежується вимогами до правової форми акта, що встановлює той або інший податок чи обов'язковий платіж, і до процедури його прийняття. Зміст цього акта також має відповідати певним вимогам. Як зауважує А.А. Пилипенко, законно встановленим може вважатися податок, що має економічний зміст і підставу. Економічною підставою податку не можуть слугувати «порожня скарбниця», «бюджетний дефіцит», «жалюгідний стан тієї або іншої галузі народного господарства». По суті, потреба в публічних фінансових ресурсах не може бути задоволена повністю. Проте сама її наявність не може вважатися достатньою підставою для фіскальних вилучень 25 .

Тож не може вважатися законно встановленим податок або обов'язковий платіж, що не відповідає, власне кажучи, конституційним принципам та основним началам законодавства про податки і збори, зокрема принципу визначеності податкового зобов'язання. Так, відповідно до ст. 67 Конституції України (у системному зв'язку з її ст. ст. 1, 24 і 64), в Україні як правовій державі закони про податки і збори повинні містити чіткі й зрозумілі норми. Отже, Верховна Рада України, відповідно до змісту Конституції України, для реалізації конституційного обов’язку громадян сплачувати законно встановлені податки і збори повинна забезпечувати чітку визначеність вимог Податкового кодексу України, тобто вони мають бути конкретними і зрозумілими. Цей конституційний принцип ще інколи називають конституційно-правовим застереженням. Зазначимо також, що принцип встановлення податків і зборів виключно законом передбачає вимогу щодо наявності в податковому законі всіх елементів оподаткування, адже податок, аби вважатися встановленим законом, має відповідати загальноправовим засадам законодавчого акта про податки і збори, який прийнятий i введений у дію у встановленому порядку26. 
Отже, зміст конституційного поняття «встановлений законом»є доволі складним і поєднує низку критеріїв, що визначають законність встановлення податків. Так, у розумінні ст. 67 Конституції України встановити податок або збір - не означає дати йому тільки назву (найменувати його), потрібно визначити в законі істотні елементи податкового зобов'язання. Тобто встановлення податку або збору виключно законом означає, що встановити податок і збір можна тільки законом і лише шляхом прямого перерахування в ньому всіх обов'язкових елементів податку. Тільки сукупність істотних елементів податкового зобов'язання встановлює обов'язок платника податків щодо сплати податку. За відсутності бодай одного з істотних (обов'язкових) елементів оподаткування (якщо законодавець 3 якоїсь причини не встановив та/або не визначив хоча б одного 3 них) податок не може вважатися законно встановленим. У цій ситуації в низці випадків платник податків має всі законні підстави не сплачувати податку або сплачувати в найбільш вигідний для себе спосіб.

Загалом податок можна розглядати як належно встановлений, якщо структура його юридичної конструкції є повноцінною. Іншими словами, встановлення істотних елементів податку - компетенція законодавця. Це передбачає, по-перше, визначення всіх істотних елементів податку саме в законі: відповідно до п. 7.1 ст. 7 ПКУ податок і збір можуть вважатися встановленими лише в тому випадку, коли встановлені всі істотні елементи оподаткування: платники податку, об'єкт оподаткування, база оподаткування, ставка податку, порядок обчислення податку, податковий період, строк та порядок сплати податку, строк та порядок подання звітності про обчислення і сплату податку27.

Податковий кодекс України змушує законодавця виконувати власні норми, що фіксують перелік обов'язкових елементів оподатковування. Як зазначає Д.В. Вінницький, законодавець вправі на власний розсуд, не порушуючи конституційних принципів, визначати істотні елементи податкових зобов'язань, однак він не вправі змінити сам перелік істотних елементів податкового зобов'язання, визнати той або інший елемент «несуттєвим», якщо в дійсності він таким є 3 огляду на саму логіку закону про податок ${ }^{28}$. Тобто вся система ПКУ побудована на основі використання конструкції елементів оподаткування, відповідно до якої податок вважається встановленим лише у випадку, якщо в Податковому кодексі України визначено всі обов'язкові елементи оподаткування, шляхом прямого їх перерахунку.

По-друге, кожний із зазначених елементів податку повинен бути належно встановлений. Підвищені вимоги висуваються до об'єкта оподаткування, з яким пов'язане виникнення обов'язку сплати податку, і податкової ставки, що визначає величину податкового відрахування. Податок мусить мати самостійний об'єкт оподаткування, який повинен бути сформульований чітко та недвозначно.

Виділення обов'язкових елементів оподаткування і закріплення їх у законі зумовлено особливою важливістю відносин у сфері оподаткування, оскільки вони заторкують матеріальні (в окремих випадках - i особисті) інтереси індивідів. Кожен елемент податку має самостійне юридичне значення, відіграє досить важливу роль для забезпечення можливості сплати податку, а також виконує конкретну функцію, оскільки наслідком неналежного визначення якого-небудь з елементів оподаткування може стати не тільки конфліктність ситуації, а й можливість невиконання обов'язку щодо сплати податків на цілком законних підставах.

Тим паче, зважаючи на важливість податкових правовідносин, у літературі висловлюється пропозиція про конституційне регулювання питання встановлення істотних елементів оподаткування. Так, на думку Г.А. Гаджієва та С.Г. Пепеляєва, враховуючи особливу важливість «питання про істотні елементи податкового зобов'язання може бути підняте на конституційний рівень або рівень конституційного закону. Це дозволило б чітко встановити межі нормотворчої діяльності виконавчої влади у сфері оподаткування, сприяло б розвитку законодавчої техніки і заразом підвищенню професіоналізму парламентаріїв» 29.

Висновки. Принцип встановлення податків і зборів (як форми обмеження права власності) виключно законом зводиться до наявності відповідної імперативної конституційної вимоги. Встановлення податків законом має важливе практичне значення, яке зумовлено тим, що податкове право, як відомо, хоч і не регулює відносин власності - його предметом є перерозподільні суспільні відносини у сфері публічних фінансів, - проте ці суспільні відносини безпосередньо пов'язані з відносинами власності, а тому є особливо чутливими, резонансними в суспільстві. Необхідність встановлення податків законами продиктована не стільки завданням забезпечити реальність їх стягнення та внесення до бюджету, скільки метою гарантувати захист власника від несанкціонованого втручання з боку інститутів публічної влади (держави, інститутів місцевого самоврядування). Конституційним призначенням системи оподаткування є захист права власності від безмежних у принципі домагань публічних суб'єктів (інститутів державної влади та місцевого самоврядування), підтримка балансу публічних потреб та інтересів. 3 позиції конституційних цінностей податкове право покликане обмежити фіскальний суверенітет держави і захищає платників від довільно, безпідставно встановлених податків.

Законодавчо встановлена система оподаткування повинна мати достатнє конституційне обгрунтування, яке дозволило б чітко визначити, на яку конкретно частину власності платника податків може претендувати публічний суб'єкт і чому. Встановлення податків не може бути довільним, тобто податки не повинні перешкоджати реалізації індивідами своїх конституційних прав. При встановленні податку і визначенні його істотних елементів мають враховуватися макро- та мікроекономічні наслідки і для державного та муніципального бюджету, і для конкретного платника податків.

${ }^{1}$ Бондарь Н.С. Конституционализация социально-экономического развития российской государственности (в контексте решений Конституционного Суда РФ). Москва: ООО «Викор-Медиа», 2006. С. 144.

2 Конституція України: Закон від 28.06.1996 р. № 254к/96-BP. База даних «Законодавство України» / BP України. URL: https://zakon.rada.gov.ua/laws/show/254\%D0\%BA/96-\%D0\%B2\%D1\%80 (дата звернення: 01.04.2020).

3 Там само.

Часопис Київського університету права • 2020/1 
4 Гаджиев Г.А., Пепеляев С.Г. Предприниматель - налогоплательщик - государство. Правовые позиции Конституционного Суда Российской Федерации: учеб. пособ. Москва: ФБК-ПРЕСС, 1998. С. 250.

5 Козырин А.Н. Публичные финансы: взаимодействие государства и общества. Москва, 2002. 37 с.

6 Тарибо Е.В. Доктрины Конституционного Суда Российской Федерации в сфере налогообложения: теоретический и практический аспекты: дис. ... канд. юрид. наук. Москва, 2005. С. 51.

7 Гаврилюк Р.О. Рішення Конституційного Суду України як джерело податкового права. Науковий вісник Чернівецького університету. Правознавство. Чернівці: Рута, 2003. Вип. 180. С. 97.

8 Гаджиев Г.А., Пепеляев С.Г. Вказана праця. С. 244.

9 Там само. С. 261.

10 Основы налогового права: учеб.-метод. пособ. / под ред. С.Г. Пепеляева. Москва: Инвест-Фонд, 1995. С. 105.

11 Пилипенко А.А. Правовое обеспечение формирования налоговой системы Республики Беларусь: дис. ... канд. юрид. наук. Минск, 2004. С. 41.

12 Соловьёв В.А. Частный и публичный интересы субъектов налоговых правоотношений: дис. ... канд. юрид. наук. Москва, 2002. С. 52.

13 Податковий кодекс України від 02.12.2010 р. № 2755-VI. База даних «Законодавство України» / BP України. URL: https://zakon.rada.gov.ua/laws/show/2755-17 (дата звернення: 01.04.2020).

14 Винницкий Д.В. Основные проблемы теории российского налогового права: дис. ... д-ра юрид. наук. Екатеринбург, 2003. C. 137.

15 Гаджиев Г.А., Пепеляев С.Г. Вказана праця. С. 271.

16 Темиржанов М.К. Конституционные основы регулирования налоговых отношений: дис. ... канд. юрид. наук. Москва, 2004. C. 134.

17 Пилипенко А.А. Вказана праця. С. 41.

18 Рішення Конституційного Суду України у справі про тимчасову надбавку до діючих ставок ввізного мита від 23.06.2009 p. № 15-рп/2009. База даних «Законодавство Украӥни» / BP України. URL: https://zakon.rada.gov.ua/laws/show/ v015p710-09 (дата звернення: 01.04.2020).

19 Конституція України: Закон від 28.06.1996 р. № 254к/96-BP. База даних «Законодавство України» / BP України. URL: https://zakon.rada.gov.ua/laws/show/254\%D0\%BA/96-\%D0\%B2\%D1\%80 (дата звернення: 01.04.2020).

20 Конституція України; Рішення Конституційного Суду України у справі про податкову заставу від 24.03 .2005 р. № 2-рп/2005. База даних «Законодавство Украӥни» / ВР України. URL: https://zakon.rada.gov.ua/laws/show/v002p710-05 (дата звернення: 01.04.2020)

${ }^{21}$ Конституция Исландии (Республики Исландии) от 17 июня 1944 г. Конституции государств Европы: в 3 т. / под общ. ред. Л.А. Окунькова. Москва: Норма, 2001. Т. 1. С. 775-816.

${ }^{22}$ Конституция Греции (Греческой Республики) от 11 июня 1975 г. Конституции государств Европь:: в 3 т. / под общ. ред. Л.А. Окунькова. Москва: Норма, 2001. Т. 1. С. 637-696.

23 Конституция Швеции (Королевства Швеция) от 27 февраля 1974 г. Конституиии государств Европы: в 3 т. / под общ. ред. Л.А. Окунькова. Москва: Норма, 2001. Т. 3. С. 581-702.

24 Затулина Т.Н. Конституционно-правовые основы регулирования налоговых отношений в Российской Федерации: вопросы теории и практики: дис. ... канд. юрид. наук. Ростов-на-Дону, 2008. С. 137.

25 Пилипенко А.А. Вказана праця. С. 25.

26 Чуркин А.В. Объект налогообложения: правовые характеристики: учеб. пособ. Москва: Юристъ, 2003. С. 26.

27 Податковий кодекс України від 02.12.2010 р. № 2755-VI. База даних «Законодавство України» / BP України. URL: https://zakon.rada.gov.ua/laws/show/2755-17 (дата звернення: 01.04.2020).

28 Винницкий Д.В. Вказана праця. С. 221.

29 Гаджиев Г.А., Пепеляев С.Г. Вказана праця. С. 250-251.

\section{Резюме}

Худик А.М. Конституційний принцип встановлення податків і зборів виключно законами України.

Стаття присвячена висвітленню одного з аспектів проблеми конституціоналізації публічних фінансів в Україні, а саме юридичної конструкції та змісту закріпленого в Конституції України фундаментального принципу правового регулювання податкової системи України - принципу встановлення податків і зборів виключно законами України. У статті аргументовано, що загальнодержавні податки та збори, відповідно до змісту ст. 67 Конституції України, можна вважати встановленими законом, якщо вони встановлені належним суб'єктом - законодавчим органом, у належній формі - формі закону про внесення змін та доповнень до Податкового кодексу України та в передбаченому законом порядку і введені в дію відповідно до чинного законодавства. Наголошено, що необхідність встановлення податків законами продиктована не стільки завданням забезпечити реальність їх стягнення та внесення до бюджету, скільки метою гарантувати захист власника від несанкціонованого втручання 3 боку інститутів публічної влади (держави, інститутів місцевого самоврядування). Тільки через прийняття відповідного закону можна зобов'язати платника податків перераховувати частину свого доходу (майна) у дохід держави, не порушуючи при цьому конституційних гарантій недоторканності права приватної власності.

Ключові слова: конституція, конституційне законодавство, конституційне право людини, податок, платник податку, власність, закон, держава.

\section{Резюме}

Худик A.M. Конституционный принцип установления налогов и сборов исключительно законами Украины.

Статья посвящена освещению одного из аспектов проблемы конституционализации публичных финансов в Украине, а именно юридической конструкции и содержания закрепленного в Конституции Украины фундаментального принципа правового регулирования налоговой системы Украины - принципа установления налогов и сборов исключительно законами Украины. В статье аргументировано, что общегосударственные налоги и сборы, согласно содержанию, ст. 67 Конституции Украины, можно считать установленными законом, если они установлены надлежащим субъектом - законодательным органом, в надлежащей форме - форме закона о внесении изменений и дополнений в Налоговый кодекс Украины и в предусмотренном законом порядке и введены в действие согласно действующему законодательству. Сделан акцент на том, что необходимость установления налогов законами продиктованная не столько задачам обеспечить реальность их взыскания и внесение в бюджет, сколько 
целью гарантировать защиту владельца от несанкционированного вмешательства со стороны институтов публичной власти (государства, институтов местного самоуправления). Только через принятие соответствующего закона можно обязать налогоплательщика перечислять часть своего дохода (имущества) в доход государства, не поднимая при этом конституционных гарантий неприкосновенности права частной собственности.

Ключевые слова: конституция, конституционное законодательство, конституционное право человека, налог, налогоплательщик, собственность, закон, государство.

\section{Summary}

Andriy Khudyk. The constitutional principle of establishing taxes and levies exclusively by the laws of Ukraine.

The article covers one of the aspects of the problem of constitutionalizing public finances in Ukraine, namely the legal construction and content of the fundamental, enshrined in the Constitution, principle of the legal regulation of the tax system of Ukraine - the principle of establishing taxes and levies exclusively by the laws of Ukraine. The article argues that state taxes and levies, in accordance with Article 67 of the Constitution of Ukraine, can be considered to be established by law if they are established by the proper subject, the legislative body, in the proper form of the law on amendments and additions to the Tax Code of Ukraine and in accordance with the procedure prescribed by law and enacted in accordance with the legislation in force. It is emphasized that the necessity of establishing taxes by the laws is dictated not so much by the task of ensuring the reality of their collecting and contributing to the budget as by the purpose of guaranteeing the protection of the owner from unauthorized interference by public authorities (the state and local selfgovernment institutions). Only through the adoption of the appropriate law one can oblige the taxpayer to transfer part of his revenue (property) to the state revenue, without violating the constitutional guarantees of the inviolability of the right of private property.

Taxing is a necessary condition for the existence of the state. The imposition of taxes by the law is of great practical importance due to public relations in the field of public finances. It is concluded that the constitutional purpose of the taxation system is to protect rights of property from public entities pursuits, which are limitless in principle, and to keep the balance of public needs and interests. From the standpoint of constitutional values, tax law is intended to limit the fiscal sovereignty of the state and to protect taxpayers from arbitrarily, groundlessly imposed taxes. The taxation system established by the law must have sufficient constitutional justification to determine clearly what specific part of the taxpayer's property a public entity can lay claim to and why. The establishment of taxes cannot be arbitrary, that is, taxes should not interfere with the exercise by individuals of their constitutional rights. Macro- and microeconomic implications both for the state and municipal budgets and for a particular taxpayer should be taken into account when establishing the tax and determining its essential elements.

Key words: constitution, constitutional legislation, constitutional human right, tax, taxpayer, property, law, state.

DOI: $10.36695 / 2219-5521.1 .2020 .25$

УДК $340.114: 342.4$

\section{І.Г. БИЧКОВ}

Іеор Геннадійович Бичков, здобувач Науководослідного інституту державного будівництва та місцевого самоврядування НАПрН України*

ORCID: 0000-0002-0523-9366

\section{КЕЛЬЗЕНІВСЬКА МОДЕЛЬ КОНСТИТУЦІЙНОЇ ЮРИСДИКЦІЇ ЯК ТЕОРЕТИЧНА ОСНОВА ЄВРОПЕЙСЬКОЇ СИСТЕМИ КОНСТИТУЦІЙНОГО ПРАВОСУДДЯ}

Постановка проблеми. Конституційний розвиток нашої країни так чи інакше сьогодні вже неможливий без урахування цілої низки фундаментальних правових доктрин, як-то «права та свободи людини», «правова держава», «верховенство права», «парламентаризм», «розподіл влади»1․ У зв’язку із цим для пошуку шляхів удосконалення системи влади та, зокрема, оптимальної моделі конституційної юрисдикції, особливого значення набуває вивчення надбань європейської доктрини конституційного правосуддя, однією з беззаперечно визначних сторінок якої є праці Г. Кельзена, що по праву вважається основоположником концепції конституційного суду та конституційного контролю в Європі.

Аналіз останніх досліджень і публікацій. Дану тематику досліджували та розкривали у своїх працях іноземні та вітчизняні вчені, а саме: К.М. Еррера, Я. Фольмайєр, О. Жуанжан, С.А. Авакьян, С.В. Боботов, М.В. Вітрук, В.О. Гергелійник, М.М. Гультай, С.В. Шевчук, М.І. Козюбра, В.П. Колісник, О.М. Мироненко, Т.П. Міхеєва, А.В. Портнов, М.В. Савчин, А.О. Селіванов, О.В. Скрипнюк, І.Д. Сліденко, П.Б. Стецюк, В.П. Тихий, Т.Я. Хабрієва, В.М. Шаповал, В.С. Чіркін, та багато інших. Водночас, не применшуючи внеску та значення цих та багатьох інших досліджень, зазначимо, що дискусійними залишається ще багато питань, які $€$ актуальними в науковому та практичному відношенні.

Формулювання мети статті. Виходячи 3 цих міркувань, мета даної статті полягає у дослідженні змісту моделі конституційної юрисдикції, запропонованої Г. Кельзеном, що свого часу фактично стала теоретичною основою сучасної європейської системи конституційного правосуддя, та визначенні основоположних елементів цієї моделі.

(C) І.Г. Бичков, 2020

* Igor Bichkov, Degree Seeking Applicant of Scientific Research Institute of State Building and Local Government of National Academy of Law Sciences of Ukraine 